\title{
Economies of scope: context of agriculture, small family farmers and sustainability
}

Amar K. J. R. Nayak

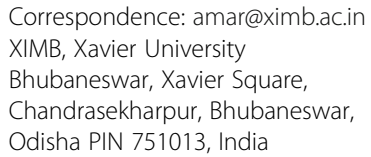

Correspondence: amar@ximb.ac.in XIMB, Xavier University Bhubaneswar, Xavier Square, Chandrasekharpur, Bhubaneswar, Odisha PIN 751013, India

\begin{abstract}
What does this article offers? It raises questions on the assumptions of efficiency in agriculture, traces the history of the logic of scale replacing logic of scope, analyses its impact on sustainability and offers a framework to discern technical contradictions of efficiency across different sectors and find a balance for sustainability. It delves with a few basic questions: First, what is the assumption for efficiency in agriculture and food production? Second, how efficiency criterion of dominant players in one leading sector decimates the efficiency wisdom of another sector?

Tracing the evolution of theory and practice of 'economies of scale' during the last three centuries of industrial revolution, the article shows the irony of adopting economies of scale time and again only to face greater economic recession, market failures, climate changes, food crisis and growing un-sustainability of our ecosystem. Through empirical evidences from small family farmers and farmer producer organizations from across India and based on the findings of eight years of action research on designing sustainable producer organization, the article highlights that 'economies of scope' in agriculture is not only more efficient for nutritious food production and climate resilience but also for sustainability of agricultural ecosystems and of overall socio-economic-environment.
\end{abstract}

Keywords: Economies of scope, Economies of scale, Sustainable agricultural systems, Small family farms, Organizational design, Institutional architecture, Sustainability

\section{Introduction}

In the last three hundred years of industrial revolution, the theory and practice of 'economies of scale' has greatly snowballed. Scale has been the basis of efficiency and growth in industrial production. Accordingly the industrial enterprises and their shareholders in the secondary and tertiary economic activities across the globe have grown and prospered. More often than not, the governments across geographies have tried to resolve the problems of unemployment and production through scale and technology. So has been the quest for scale under the aegis of globalization.

In the context of increasing mainstreaming of ideas of economies of scale in agricultural production and its associated features across value chains in agriculture; this article explores into whether this mainstream thought is relevant to agriculture, small producers and retail consumers of agricultural products. Empirical evidences from a transitional economy like India from the domain of agricultural production, enterprises 
of smallholder farmers, purchase preference of retail consumers seem to suggest otherwise.

In the above light, this article analyses the relevance and significance of 'economies of scope' in the context of agriculture and smallholder farmers from efficiency and sustainability perspective. The comparative analysis of industry and agriculture for respective efficiency shall be on four key aspects viz., (a) basis of efficiency in different sectors, (b) dynamic relationship of scope and scale in primary, secondary and tertiary sectors, (c) empirical evidences on performance of smallholder farmers under economies of scale and scope, and (d) challenges in organizational design and institutional architecture in the light of economies of scope.

As a prelude to above analysis, let us first take a quick review of evolution of the idea of economies of scale since 1770s and the intermittent debates on economies of scope in the 1950s and 1970s and subsequent mainstreaming of economies of scale and industrial organizational designs as engines of growth leading to a gradual death of the idea of economies of scope.

\section{Economies of scale: evolution of practice and theory}

The revolution of agriculture probably occurred in the Middle East about ten millennia years ago and independently developed in other parts of the world. People lived in small communities and cultivated for their own consumption. To avert risks of famines and floods, people tried to grow more than required for consumption and stored them for potential natural calamities. However, the nature of agriculture remained to be small, ecosystem specific and largely self-sufficient especially in geographies like the Indian sub-continent in the temperate zone with abundant flora and fauna. 'Economies of scope' has been a powerful idea for achieving operational efficiency in agriculture as well as industry until the middle of eighteenth century.

With the development of science and technology, came the Industrial Revolution in the eighteenth century. This second revolution of mankind has indeed greatly impacted the lives of human beings. It has not only transformed the nature and quality of human life but has also transformed the first revolution of agriculture and our ecosystems as a whole. From an open production system in agriculture, industrial revolution adopted the closed production system by way of factory production. Factories were owned by the rich and wealthy individuals, where operational efficiency became the major concern of factory managers as would be desired by the owners of these factories. Unlike in an open system, many of the variables of production could be controlled in a closed factory production system and hence the efficiency of operations surely improved in such systems.

Since the factors of production could be controlled, there was scope for individual owners and their managers to better manage the variables and hence be more efficient. Increase in scale of production led to lowering costs and hence was a natural logic for greater efficiency. Greater efficiency in production attracted more entrepreneurs to invest in the factory system of large production. Scale lowers cost of production (Dobrev and Carroll 2003) and helps in several ways such as (a) purchase and make use of specialized manufacturing equipment, (b) derive saving from operational expansion and quicker pay back of investments in production facilities and capacity expansion, (c) promote in-depth employee specialization based on an intricate division of labour, (d) 
extract rent from experiential learning and benefits of high frequency with which same tasks are carried out, and (e) reduce per unit overhead cost.

Scale also facilitate gain substantial market share in a competitive market. This helps large scaled firms to force customers and suppliers to become price takers as well as to review their own strategies in light of their dependency on local firm. Scale also serves as a strong barrier to entry for new entrants in an industry.

These obvious advantages of scale in industrial production have caught the imagination of the economists from the time of Adam Smith in the 1770s; from the beginning of industrial revolution. While the idea of 'economies of scale' has been the mainstay of discussion and research among the economists since 1770s, the idea of 'economies of scope' have appeared intermittently within the history of economic thoughts. In his book Wealth of Nations, Smith (1776) discusses the notion of economies of scope in the light of how division of labor is limited by the extent of the market for a product or service. He observed that a person needs to engage in multiple activities because the product or service that a person offers is limited to the nearby smaller market and cannot be sold in far off and large markets. In other words, scope limited growth and for one to reach his product or service in far off larger markets, he has to specialize on a particular product or service. In the context of industrial culture and production economics, Adam Smith and the other leading economists were indeed right and rightly so, they unintentionally buried the idea of economies of scope.

As the industrial enterprises grew with the growth in industrial production and trade, several social, cultural, and environmental issues emerged. Marx (1927) described the problems of value appropriation of labor by owners of enterprise and alienation of man from his life and culture due to over mechanization and industrialization. Schumacher (1973), on the other hand argued that capitalistic model of production led to creative destruction and loss of value for the society; which may therefore ultimately collapse from its own internal contradiction and weight. However, the idea of economies of scale as propounded by Smith and others along with industrialists who had a great appetite for growth; kept the idea of scale to grow. That the division of labor is limited to the extent of market; proposed by Smith was reiterated by Stigler (1951).

With markets becoming more competitive industrial products during the first 200 years of industrial revolution, the idea of economies of scope reemerged in 1970s. Panzar and Willig (1975) brought it back to the discourse of economic thinking by arguing for economies of scope in multi-output production. Teece (1980) extended this idea by his empirical observations of scope for diversification to multi-output from single input especially in petroleum industry in USA. Economies of scope in business and product diversification were seen as ways to open new avenues of growth in highly competitive industries and markets. The ideas of scale and scope were however applied largely to industrial production systems at secondary level production.

To the broader arguments of Marx on Capitalism, North (1984) argued instead that the core problems of both capitalism and communism lay in specialization and division of labor. Further, explaining the limitations of transaction cost analysis, North (1984) argued that economies of scale built on basis of specialization and division of labor that was supposed to reduce transaction costs neglected to recognize the significant increase (nearly 50\%) indirect transaction costs. 
Despite observations on limitations of industrialization and mass scale production; clear benefit of greater efficiency of production through scale led to formation of large enterprises. In the United States of America, firms followed a three pronged investment strategy to invest in production, managerial pool, and distribution to grow ahead of the European firms (Chandler 1990). Europe and Japan soon caught on with this strategy of growth.

With larger scale of production, supply often overtook demand. This would occur because scale based production is a step function due to indivisibility of production technologies. With greater competition, local markets in these industrial economies saturated gradually and hence surplus production had to be exported out to other markets. Hence, the logical step to scale was expansion of markets through geographic expansion; with which began the globalization of business. From 1880s, international trade and business grew uninterrupted till around 1920s. War \& economic recession in 1920s favored state intervention in industrial economies. Keynes (1936) argued for welfare state through his book, General Theory of Employment, Interest and Money. These arguments supported the government investments in large scale state owned enterprises during 1930s to 1970 s.

Despite the argument for smaller production and implementation of the New Economic Policy under Lenin in USSR by Kondratiev (1921), Stalin followed the large scale production through the large state run enterprises. Many of the European countries including United Kingdom, Germany and France also promoted several large state owned enterprises in the nineteenth century. Following the global trends, countries like China and India promoted large scale state owned enterprises since they became independent in 1950s.

To facilitate global trade and business arising out of surplus production and recession in western industrial economies during the inter-war period, 1919-1939, Bretton Woods Conference (July, 1944) chaired by Keynes proposed formation of international agencies viz., World Bank, International Monetary Fund (IMF) and International Trade Organization. The basis for these global institutions fitted the idea of managing scale through global expansion of markets. While World Bank and International Monetary Fund was approved by the 44 Allied Nations that attend the conference, International Trade Organization was approved only as a milder version as General Agreement on Tariffs and Trade (GATT).

The establishment of these three international organizations created conditions for global expansion of markets by enterprises of industrialized countries. However, expansion of markets in developing countries by large enterprises from western countries was stalled during 1950-1970 by protective mechanisms imposed by countries like India and China that were former colonies of western countries and became independent after the Second World War (Jones, 1996).

Following protective measures on imports by newly independent countries in Asia and Africa, large enterprises from western countries could not offload the surplus production in the western industrial economies. This resulted in greater competition within and among the industrial economies. From scale, the source of competitive advantage became technological innovations. As a result of market saturation and very high competition based on technological innovations, many of the large enterprise, especially the state owned enterprise became unviable. This led to the beginning of privatization of state owned enterprises in western countries. 
The three global institutions of World Bank, IMF, and GATT through various negotiations and coercive methods have been able to push the developing countries to gradually open up their markets. Hence after a slow down of global business for about 50 years (1920-1970), it began to revive from the late seventies (Jones, 1996, Nayak 2008).

Despite international political maneuvering for global expansion of markets, industrial economies could not balance their production capacity with the expanded global markets. Observing the problems of scale in industrial production; its negative impacts across the countries, a wave of thought emerged in 1970s. Schumacher (1973), argued for appropriate technology that could be small and hence sustainable. Scholars working on multinational corporations that operated on scale and trends of global trade and investments had also begun to perceive the dangers of large corporations. Vernon $(1971,1977)$ argued that the large corporation through their scale of operations could undermine the sovereignty of other small countries.

However, as global trade and business picked up in the 1970s (Jones, 1996, Nayak 2008), the industry magnates, policy makers and international agents of trade and commerce pushed forward the ideas of large scale operations. The excitement of growth and prosperity through large scale production' although for a few in industrial economy, was blissfully ignored by scholars and academia for any deeper analysis. In addition, by the 1990s, with maturing of practices and theories of private property rights, commercialization and control of innovations in products, process technologies and coercive opening up of global markets; market competition intensified globally. To cope up with the intense competition, a wave of strategic mergers and acquisitions in USA and Europe began in 1998. Accordingly, countries across the world had begun to relax the clause to restrict monopolies in order to protect private corporations of their respective countries, as it otherwise threatened business and employment of key stakeholders in their respective countries.

The scholarship in management science since 1990s had more observations and ammunition to argue for specialization at the firm level to be competitive in global markets. Prahalad and Hamel (1990) argued for focusing on core competence and argued for strategically managing the external forces to keep the barometer of profits of business entities. True to their allegiance to the idea of corporate growth and private wealth creation, management scholars took great pride in spreading these ideas of economies of scale in classrooms of business schools where the future managers of corporations were to be groomed. Chandler (1990) observed that enterprises across America, Britain and Germany had pursued scale and sometimes scope of multiple outputs to expand their business. Multinational enterprises that were perceived to be the engines of growth (Jones, 1996) by some business historians, was being deemed as leviathans of global society by other set of business historians (Chandler and Mazlish 1995). The explosive growth of Indian multinational enterprises during 1991-2010, in the post liberalization, privatization and globalization period has largely been an outcome of maneuvering capacity of the owners of large enterprises over various political, industry, social, and knowledge networks (Nayak, 2011).

After 50 years of its inception at the Bretton Woods Conference (1944), GATT finally in 1995 culminated as the World Trade Organization to regulate international trade and business. These three global institutions viz. World Bank, IMF, and World Trade 
Organization systematically argued for liberalization, privatization and globalization in developing countries and even in erstwhile USSR. Since the 1990s, there has been a great momentum in expansion of global trade and business. Subsequent intensive global competition has led to large scale mergers and acquisition across industries and across the globe furthering the idea of economies of scale.

During these three centuries, industrial economies have faced several business cycles, economic slowdown and recession, battle over currencies, economic war, political war, and alarming climate changes. Ironically, the problems of one business cycle are attempted to be resolved by applying more of the ideas of economies of scale. It appears that economies and industries are locked into scale and specialization for survival. Whether the outcomes of policies based on scale and specialization led to global economy moving from bad to worse over these business cycles is yet to be analyzed. The summary of the evolution and spread of the idea of economies of scale with some brief interjections by the ideas of economies of scope to mainstream discourse of economics during the last three centuries is shown in Fig. 1.

\section{Basis of efficiency in agriculture versus industry}

What has been the basis of efficiency and sustainability: economies of scale or economies of scope? Are the bases of efficiency similar or different for agriculture and industry? It is increasingly being pointed out that sustainability of agriculture shall depend on systematic and scientific management of soil, seed, moisture, plant protection and integration of agriculture. More than the external industrial inputs of fertilizers, chemicals, pesticides, healthy soil management have been explained to be the key to high yield and sustainable production (Howard 1943, 1947). Soil health is linked to overall management of other dimensions of moisture management, seed, cropping pattern, and integration of agriculture with livestock and forestry. All these improve the micro ecosystem that enhances the condition for better plant protection and better agriculture (Collettte et al. 2011, Rupela 2011).

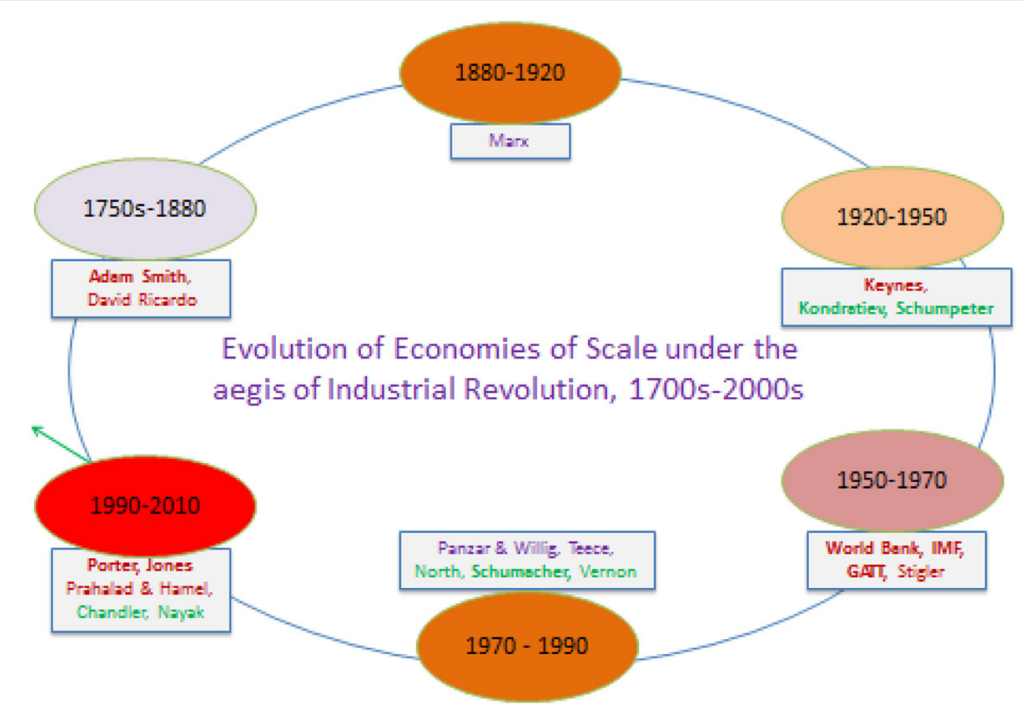

Fig. 1 Evolution of Economies of Scale under the aegis of Industrial Revolution, 1700s-2000s 
Similarly, scientific experiments in recent years in India prove the above points (Gopalakrishnan et al. 2012, Panneerselvam et al. 2013). A large number of research studies across India also lead to the same conclusion that productivity and efficiency in agriculture lay in sustainable agriculture practices (Shiva 1993, Alvares 2009, Nayak 2012a, 2012b, CRIDA 2013, and Nayak 2014a, 2014b, 2014c).

International research and studies across the world by different agencies are also building up the argument that agriculture has to adopt sustainable methods by following the basic principles of bringing back life to soil through integrated agro ecological agricultural practices (IAASTD 2009; Third World Network 2012, and UNCTAD 2013). Several research reports from across the world indeed argue for small scale diversified and integrated methods of agriculture. These seem to be a logical flaw of adopting 'economies of scale' in agricultural ecosystem unlike the logic of scale in industrial production.

The core contextual difference between agriculture and industry is on the nature of production system. On the one hand, high bio-diversity in the life systems, deep interconnections and high levels of interdependence characterizes the open system of agricultural production. On the other hand single product specialization, sequential, linear and uni-directional relationships are the characteristics of a closed industrial production systems.

Contrary to the basis of efficiency in a closed system, the basis of efficiency in an open system is high degree of interdependence and cooperation. High frequency of interactions and high degree of relationships among various actors and actants are sources of efficiency in production. The network of relationships is often dense and complex in nature with bio-diversity as the essence of such networks.

Plant as a source that converts solar energy to plant biomass and food crops; exhibits a dynamic interrelationship of sunlight, moisture, air, soil, plant/crop bio-diversity, micro-organisms, livestock and seeds for sustainable production in an open agricultural ecosystem. In other words, economies of scope seem to provide a coherent logic of agricultural ecosystems and the basis of efficiency and sustainability in agriculture.

\section{Characteristics of owners in agriculture versus industry}

It is also important to understand the characteristics of owners and actors of production in agriculture and industry. On the one hand, over $70 \%$ of owners of production in agriculture are smallholder farmers. Their resource base in terms of assets, capital, technology, information, modern equipment and associated skills are rather weak. Their capabilities are more on indigenous knowledge and techniques of production and most of their resources are in the form of common resources. On the other hand, owners of industrial production comparatively have greater asset, capital and technology base that are governed by private property rights. Given different levels of factors of productions and principles that govern them; mechanism to achieve efficiency could be quite different for these two diverse groups of producers.

Moreover, while the purpose of an investor/owner in an industrial production system is to rotate capital to generate greater return on capital invested; over $70 \%$ of owners involved in agriculture are into subsistence agriculture with a purpose to ensure food and nutritional security of their families. With the above differing objective functions and characteristics, one of the alternate logics of efficiency viz., economies of scale or 
economies of scope seem to be have been appropriate to entrepreneurs in industry and smallholder farmers in agriculture. However, the dominant logic of one sector might drive the other sectors.

\section{Dynamic relationship of scope and scale across sectors}

Where does the point of control lie at different stages of an emerging agrarian economy and how does the direction of control shift across primary, secondary and tertiary sectors in an economy over time that create a lock-in effect for policy and technology. The dynamic relationship of scope and scale at different stages of economic activity in a sector; especially agriculture could possibly provide an understanding to core of lock-in effect problem.

In the first stage of evolution of an economy, agriculture; primary sector typically is the main driver of an economy. In the second stage of evolution, secondary or manufacturing sector including value adding activities of agricultural produce drives the economy. As the economy matures, tertiary or service sector which includes retailing of food products drives the economy.

As value chain of primary, secondary and tertiary economic activities of agriculture evolves and matures, the point of gravity moves from community of farmers to secondary level processing factory. For some period of time, processing factory becomes the centre of gravity in value chain that balances both the farming community and retail outlets/chains (intermediate market place). As the retail outlet/chain grows larger, it develops good hold over final consumers and grows in its size of business. It becomes the centre of control on other actors of the value chain. The direction of control over time gradually shifts from farmer to marketer and finally the direction of control of what is to be produced and at what price is reversed.

As the focus of control shifts to manufacturer-food processor, who is preoccupied with the efficiency of capital employed in a factory, will naturally adopt economies of scale. In return the manufacturer-factory processing unit will promote production of a single crop (say baby corn) that his/her factory specializes in processing and packaging. In the subsequent stage, tertiary economic agent viz., owner of a large retail chain or a large exporter of processed food may emerge to be the centre of gravity or the point of control in agriculture value chain. The primary concern of this tertiary actor, efficiency of capital employed for marketing shall be best with economies of scale. Accordingly, demand and price mechanism for single product (say baby corn) both at secondary level and tertiary level of this value chain will alter the cropping pattern of the farming community and make them largely a baby corn producing community.

Figure 2 represents the different stages of an economy and the associated centre of gravity and how the direction of control shifts; transforming the cropping pattern at the farmers' level and reduction in choice of products at the final consumer level.

Scale of operation of individual enterprise in value chain appears to determine the power of control. Among the three actors in value chain, capacity to engage in large scale operations is available with either the owner of food processing unit or the owner of the large retail chain / processed food exporter. Given the limited resource base, it is unlikely that the smallholder farmers become the centre of gravity in the evolved value chain under the industrial product-market economy. Hence smallholder farmer is 


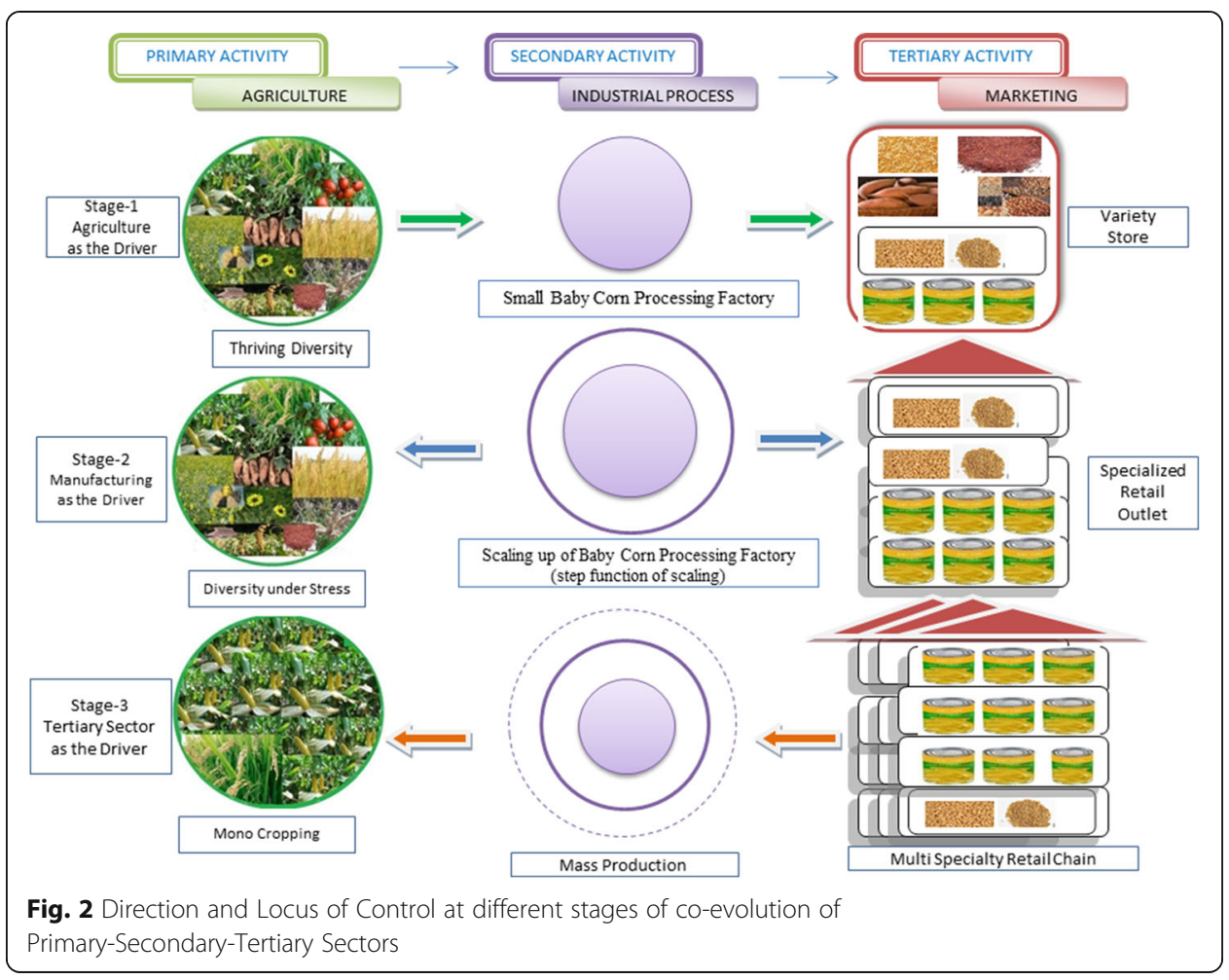

bound by the demands of secondary and tertiary sectors that are driven by the logic of mono-cropping or economies of scale.

Given the logic for scale by the intermediaries in secondary and tertiary stages, smallholder farmers are forced to adopt mono-cropping practices. At the cost of his own sustainability and sustainability of agricultural ecosystem, smallholder resource poor farmer seems to subsidize the efficiency and growth of actors in secondary and tertiary sectors in agricultural value chain. The source of tension between smallholder farmers and intermediaries of secondary and tertiary sectors is hence clear.

The tensions across these three sectors arise out of multiple perspectives, viz., moral, technical, and systems perspectives. On the moral perspective; whose efficiency viz., smallholder farmers, investors in processing facilities or investors in retail chains should be of greater importance. On the technical perspectives; which technical efficiency viz., nutritional efficiency of smallholder farmers, production efficiency of food processor or operational efficiency of the retailer should be prioritized. On the systems perspective; how different types of institutional architecture and relationships are critical for sustainability in each of the three sectors. Table 1 provides the details of the three perspectives under different stages of economic activity.

\section{Organizational design \& institutional architecture: challenges}

If we recognize that the logics of efficiency viz., economies of scope and economies of scale are different for agriculture, factory manufacturing and retail business and that these economic activities are deeply interconnected with each other, the first challenge is to appropriately design organization with one or the other logic. The second and more challenging issue is how to develop an institutional architecture such that 


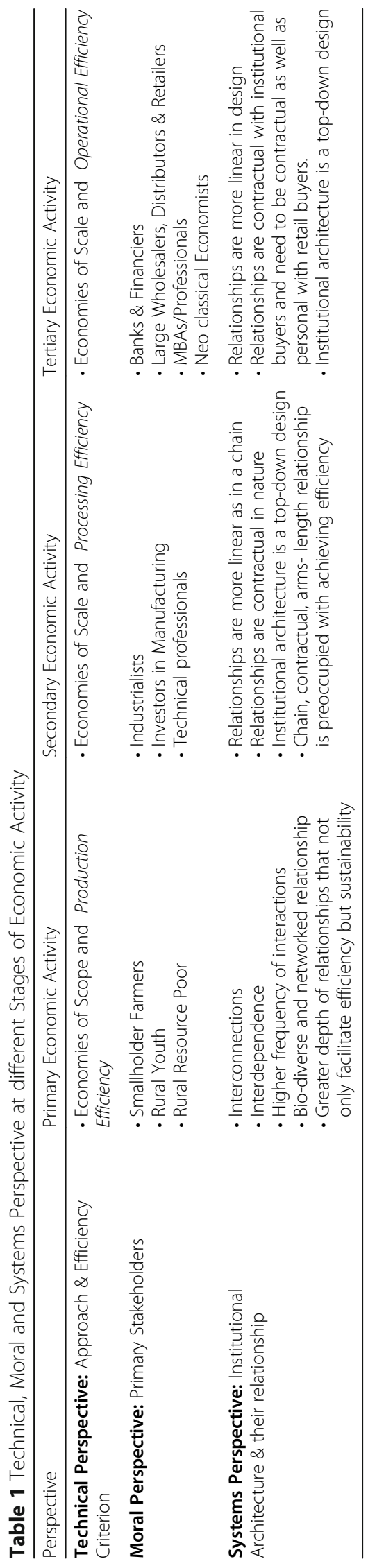


tensions across the three sectors are optimally balanced to ensure stable relationship and sustainable governance.

Depending on the logic of efficiency adopted, whether scope or scale; associated organization design variables viz., size, technology, ownership, and management will vary. The deep seated logic, language and values will be different for each of these paradigms (Nayak 2014a, 2014b, 2014c). The institutional architecture could vary from being top-down under scale economies to bottom up under scope economies. Further, under scope economies, there would be optimal lower and upper limit to institutional architecture unlike the borderless view under scale economies.

As in industrial production system, institutional architecture for agriculture is also top-down. Policies and programmes flow down from central and state governments to local institutions. These programmes are also controlled from the top making local institutions very weak. Empirical observations suggest that policies and practices on the ground do not seem to observe these differences. Performance of farmers and farmer producer organizations that do not distinguish these differences also show varying performance. Indeed, there is very little research on whether there exist an optimal lower limit and upper limit of institutional architecture for agricultural systems to be sustainable.

\section{Empirical evidences across India}

\section{Performance of smallholder farmers adopting scale versus scope}

India has had rich bio-diversity and highly productive low cost integrated agriculture systems, as applicable to local soil and agro climatic conditions and over many millenniums of agriculture in India. However, over the last two hundred years, the low cost producer oriented agriculture has been converted to the high cost market oriented plantation and mono crop system (conventional - green revolution). The usage of industrially produced fertilizers, chemicals and pesticides has gradually transformed the characteristics of agriculture during the past 5-decades across India and the world.

Smallholder farmers adopting precision agriculture; adopting mono-cultures with large external industrial inputs are becoming unviable across India. Farmers in Punjab, where external input intensive agriculture was undertaken through green revolution for about 40 years, today has an average debt of about $42,000 \mathrm{INR}^{1}$ as compared to national average of 20,000 INR. In one of the so called agriculturally better off districts (Balasore) in Odisha, a baseline study in 2013 of over 4000 farmers revealed that about $30 \%$ of farmers were making loses across six major crops from cereals, pulses, and oil seeds and nearly $50 \%$ of the farmers are financially unviable in their farm production practices (Nayak 2013a, 2013b). Most of the farmers in this district have been adopting mono cropping (economies of scale) with intensive external industrial inputs like inorganic fertilizers, pesticides and herbicides.

The realization of negative impacts of industrial inputs in agriculture, pesticide residues in food, especially in respect of small holder producer communities, has led to a resurgence of various low cost smallholder farmer and consumer friendly alternatives, replacing the high risk and cost (including environmental and human costs) of external input based agriculture. There are indeed a variety of agricultural systems in India and across the world. These have been responses to the crisis arising out of conventional scale 
economies based industrial agriculture systems in both production and distribution. Some of the major variants of sustainable practices and concepts have been agro ecology, sustainable food systems, ecological agriculture, sustainable agriculture, integrated agriculture, low external input sustainable agriculture, organic farming, natural farming, natueco farming, bio-dynamic farming, permaculture, zero budget Farming, indigenous microorganism based farming, effective micro-organism based farming, etc.

Farmers adopting any of the above sustainable practices using the principle of economies of scope in agriculture that is multiple cropping patterns and integrated agriculture are found to be much more productive. Due to low cost of agriculture, better shelf life and better prices for their produce, these farmers also get higher net incomes. In about one hectare of land, such farmers are able to make an average net income of about INR 50,000 per month. There are several such examples of farmers across different micro-climatic conditions in various states of India viz., Kerala, Tamil Nadu, Karnataka, Andhra Pradesh, Maharashtra, Gujarat, Madhya Pradesh, Odisha, West Bengal, Assam, Sikkim, Meghalaya, Rajasthan, Haryana, Punjab, Uttarakhand, and Kashmir (Nayak 2012a, 2014b).

\section{Performance of farmer producer organizations adopting scale versus scope}

There have large number of Farmer Producer Organizations in India. Formation of primary agricultural cooperative societies (PACS) was initiated in India as early as in 1904; over a hundred years ago. Today we have over 94,000 PACS in India. With growing industrialization and competition, single product based large cooperatives have also been promoted since 1950s. Today we have large cooperatives in sugar, textile, coir, etc. The self-help group (SHG) movement began in 1980s, and today there are about 9 million SHGs in the country. Since 2002, there has been a movement for promoting farmer producer organization (FPO) as producer companies. As a hybrid of company and cooperative, producer company format is being perceived as the panacea to solving problems of small producers, agriculture, and impending food crisis.

Empirical evidences on the performances of these forms of producer organizations across the country show that most of these organizations are unviable. Interestingly, most of these organizations are either designed or have the intent to be modeled around the designs of an industrial organizations; that is on the principle of economies of scale. This leads to adoption of high end technology, high capital investment, focus on large and far off markets, engagement of costly external professional for management and concentrated private ownership structures.

Early Producer Companies from the states of Kerala, Tamil Nadu, Rajasthan, Maharastra, Madhya Pradesh, Jharkhand, and Bihar have had poor financial performances (Nayak, 2014). The benefits to the farmers/producer from these producer organizations have been marginal. In summary, performance of producer organizations on different sustainable performance indicators viz., (a) social capital formation, (b) financial capital formation, (c) capability enhancement of producers, (d) external networks with markets and financial institutions, and (e) engagement of producer organization with diverse needs of the community have been low.

Among the dairy cooperatives based on single input of milk, a sector that has received much technical and financial support during the last about 40 years, the above 
performance indicators have begun to decline. The average income for dairy farmers across different dairy cooperative is around INR 2500 per month. The trends from AMUL, the largest and well known dairy cooperative is indeed revealing. Empirical evidences on dairy based farmers suggest that a farmer family can be viable with five or more number of milking cattle. However, currently about $73 \%$ of 3.2 million farmer members of AMUL have less than five cattle. Despite, $85 \%$ of every rupee earned by GCMMF (marketing wing of AMUL) being given back to its members; average net income earned by the members is only INR 3405 per month.

Further, the members from AMUL have been gradually withdrawing from dairy activity due to increasing cost of animal fodder. Today fodder is being imported by Gujarat from other states. Although, the volume of milk procured by AMUL has never come down since its inception; it however has been depending on outsourcing milk from non-members from other states. The present Managing Director of AMUL feels that with cropping pattern having changed from integrated agriculture to mono-cropping with green revolution in agriculture and industrialization in Gujarat, it is difficult to reverse the growing shortage and increase in price of animal fodder. This will lead to decline in supply of milk AMUL in the next about five years said the Managing Director of AMUL (Interview on August 30, 2013, All India Baseline Study of Producer Companies and Natural Farming Practices: Part 1, 2014, National Bank for Agriculture and Rural Development, Government of India).

On the contrary, the performance of a few farmer producer organizations that have stayed small but operated on multiple scope have provided more value to its farmer members. AMALSAD, a primary agricultural cooperative society in Gujarat is one such example. The membership of this cooperative has been around 3000 from a cluster of 17 villages. Its annual turnover is about INR 420 million. Since its beginning (1941); its engagement has been determined by needs of its members; whether it were microcredit, retail supplies, farm inputs, marketing of surplus produce of different crops, etc. Today, it also runs a hospital and petrol pump to meet the needs of its community. The average monthly income of its members is around INR 12,000 per month and the net income is over INR 7000 per month.

There are a few other such smaller and multiple product based farmer producer organization that have either focused on local markets, or sustainable agriculture. The benefits to the members from these producer organizations seem to be sound and sustainable. After trying different alternatives, few more producer organizations such as Deccan Development Society, Mahila Umang, etc. have begun to adopt local marketing with multiple products (Nayak 2014c).

Further, action research on establishing sustainable community enterprise system through the experiment of Nava Jyoti PC during 2009-2017 shows that there can be significant performance improvements on all the sustainable indicators by following the sustainable design principles viz., small size of organization, greater diversity of activities by producer organization, sustainable agriculture and appropriate technologies, and selling produce in local markets (Nayak 2012b, 2013a, 2013b, 2014a, 2017).

\section{Summary and future research}

At the base of our production pyramid, basic energy conversion processes of plants and agricultural ecosystem is highly complex and interdependent process. The 
processes at this level appear to be based on the science of interconnectedness and interdependence of sunlight, moisture, air, soil, plant/crop bio-diversity, micro-organisms, livestock and seeds. In other words, 'economies of scope' rather than 'economies of scale' is indeed the science of efficiency and sustainable production at the primary food production level. The perspective of 'systems thinking' rather than the perspective of 'linear thinking' can explain these dynamics of production in nature.

Further, resource (land) position and capability of producers does not technically favor economies of scale in either at stage of agricultural production or at subsequent stages of value addition. From a nutritional security and convenience (lower transaction cost) point of view, economies of scope is also efficient and sustainable in agriculture. Empirical evidences on performance of integrated agricultural practices at the farmer level and performance of farmer producer organization in terms of total benefit to small family farmers across the country strongly support the logic of economies of scope for greater efficiency and overall sustainability of farmers and agro-ecological systems.

The discussion on ideas of scope and scale, the key pillars of two major revolutions of human history viz., agriculture and industrial revolution is indeed a discussion of the ongoing battle between these two revolutions. The mainstream scholarship till date has hardly dealt seriously with the idea and significance of economies of scope. Since industrial revolutions during the last three hundred years, there have been limited and short lived interjections on the ideas of economies of scope. More importantly, the idea of economies of scope and its science with regard to agricultural ecosystems has not been explored by the scholarship and hence the policy on agriculture across the world has grievously gone against the nature and poses serious challenges to our sustainability.

In the above context; first, serious research and scholarship on the science of economies of scope in agro-ecological systems is required to sensibly guide policy on agriculture across the world before we further undermine and destroy our food production and ecosystem. Second, there is a huge research need and opportunity to determine optimal organizational design on specific design variables viz., size, technology, management and ownership with reference to scope. Third, research on optimal institutional architecture to ensure stable relationships among these farmer producer organizations is rather crucial to ensure sustainable global food production, nutrition food safety, and lower transaction cost of food distribution.

\section{Endnotes}

${ }^{1}$ Exchange Rate as on July 2013 was INR $80=1$ Euro. This rate may be referred to all INR indicated in this article.

I would like to thank all the farmers practicing sustainable agriculture across India who gave me the confidence to explore this idea. Mr. Subash Sharma and Mr. Deepak Suchde are few such farmers. I would like to thank the scientists, researchers, environmentalists, and activists and especially to Dr. Om Rupela, Dr. Peter Kenmore, Mr. Subhash Mehta, Dr. Claude Alvares \& Dr. Bharatendu Prakash for providing me the lead to the subject of sustainable agriculture. I also thank Professor (Dr.) Gregory Szell and Professor (Dr.) Anup K Dash for their valuable feedback and review comments. I would like to thank the National Bank for Agriculture and Rural Development for the NABARD Chair Unit; the works of which has contributed to development of these ideas. I would like to thank Xavier University Bhubaneswar and National Institute of Social Work \& Social Sciences Bhubaneswar for their support for action research on sustainable agricultural system. 
Author's information

Amar K. J. R. Nayak is Professor of Strategy and NABARD Chair Professor.

\section{Competing interests}

The author declares that he has no competing interests.

\section{Publisher's Note}

Springer Nature remains neutral with regard to jurisdictional claims in published maps and institutional affiliations.

Received: 6 September 2017 Accepted: 8 January 2018

Published online: 06 February 2018

\section{References}

Alvares, C. 2009. The organic farming source book, Other India Press and Third World Network.

Chandler, A D Jr. 1990. Scale \& Scope: The dynamism of industrial capitalism. USA: Harvard University Press.

Chandler, A D Jr, and B Mazlish (eds). 1995. Leviathans: Multinational corporations and the New Global History. Cambridge University Press, Cambridge.

Collettte, L, and et al. 2011. Save and grow: A policy maker's guide to the sustainable intensification of smallholder crop production, Food \& Agricultural Organization, UNO, Rome.

CRIDA. 2013. National Workshop, Rainfed farming systems program under $12^{\text {th }}$ five year plan: Evolving operational framework. Hyderabad: CRIDA.

Dobrev, S.D., and G.R. Carroll. 2003. Size (and competition) among organizations: Modeling scale-based selection among automobile producers in four major countries, 1885-1981. Strateg Manag J 24 (6): 541-558.

Gopalakrishnan, S., et al. 2012. Plant growth-promoting traits of bio control potential bacteria isolated from rice rhizosphere. Springerplus 1: 71

Howard, A. 1943. Agricultural Testament, Oxford University Press, England.

Howard, A. 1947. The soil and health - A study of organic agriculture. Kentuchy: The University Press.

IAASTD. 2009. Agriculture at a crossroads, international assessment of agricultural knowledge science and technology. Washington: Island Press.

Jones, G. 1996. The Evolution of International Business: An Introduction, London and New York: Routledge.

Keynes, J M. 1936. The general theory of employment, Interest and Money. UK and USA: Palgrave Macmillan.

Kondratiev, N D. 1921. New economic policy, $10^{\text {th }}$ congress, All Russian Communist Party.

Marx, K 1927. Economic and philosophic Manuscript of 1844.

Nayak, A.K.J.R. 2008. Multinational in India, FDI and complementation strategy in a developing country. London: Palgrave Macmillan.

Nayak, A.K.J.R. 2011. Indian Multinational: The Dynamics of Explosive Growth in a Developing Country Context, Palgrave Macmillan, Hamshire and New York.

Nayak, A K J R 2012a. Integrated Low Cost Agriculture for Internal Consistency and External Synergy for Sustainability of Smallholder Farmers: Case of Nava Jyoti Agricultural Community, Sustainability Seminar Series 4.0, August 2012, NABARD chair unit, XIMB.

Nayak, A K J R. 2012b. Implementing community Enterprise system for sustainability of rural agricultural communities A manual. New Delhi: NABARD-XIMB-RBF Publication.

Nayak, A K J R. 2013a. Implementing community Enterprise system for sustainability of rural agricultural communities A manual, $2^{\text {nd }}$ Edition. New Delhi: NABARD-XIMB-RBF Publication.

Nayak, A K J R. 2013b. Report on baseline survey of farmers under the pilot project for augmenting farm productivity in Balasore District, Odisha, A study under NABARD Chair Unit, XIMB.

Nayak, A.K.J.R. 2014a. Logic, language and values of cooperation versus competition in the context of recreating sustainable community systems. Int Rev Socio/ 24 (1): 13-26 Routledge.

Nayak, A K J R. 2014b. All India baseline study on natural farming practices, A study under NABARD Chair Unit, XIMB.

Nayak, A K J R. 2014c. All India baseline study on producer companies, A study under NABARD Chair Unit, XIMB.

Nayak, A.K.J.R. 2017. Optimal Institutional Architecture of Farmer Producer Organizations for Sustainable Value Creation for Small and Marginal Farmers in India Studies in Business, Economics. In Financing Agriculture Value Chains in India, Springer Nature, ed. Gyanendra Mani et al.

North, D.C. 1984. Transition costs, institutions and economic history. Zeitschrift fur die gesamteStaatswissenschaft. J Institut Theor Econ 140 (1): 7-17.

Panneerselvam, P, and et al. 2013. Food security of small holding farmers: Comparing organic and conventional system in India. Journal of Sustainable Agriculture, 35(1).

Panzar, J, and Willig, R. 1975. Economics of scale and economics of scope in multi-output production. Econ. Disc. Paper no. 33, bell laboratories.

Prahalad, C.K., and G. Hamel. 1990. The core competence of the corporation. Harv Bus Rev 68, no. 3: 79-91.

Rupela, OP. 2011. Of Soil, Subsidies, \& Survival, A report on Living Soils, Greenpeace.

Schumacher, E F. 1973. A study of economics as if people mattered. Bloride \& Briggs.

Shiva, V. 1993. Monocultures of mind: Perspective on biodiversity and biotechnology. Zed Books, London and New York and The Third World Network, Penang, Malaysia: Palgrave Macmillan.

Smith, A. 1776. Wealth of nations. Oxford: Oxford university press reprint 1993.

Stigler, G. 1951. The division of labor is limited by the extent of the market. J Polit Econ 59: 185-193.

Teece, D. 1980. Economics of scope and scope of enterprises. J Econ Behav Organ 1(3):223-47.

UNCTAD. 2013. Wake up before it is too late, Trade and Environment Review. USA: UNCTAD.

Vernon, R. 1971. Sovereignty at bay: The multinational spread of V. S. Enterprises. New York: Basic Books.

Vernon, R. 1977. Storm over the multinationals. The real issue. London: Macmillan Press. 